\title{
Orman Kanunu'nun 16'ncı maddesi uygulamalarında alınan bedellerin hesaplanma yaklaşımının değer belirleme yöntemleriyle karşılaştırmalı irdelenmesi
}

\author{
Kenan OK (Orcid: 0000-0002-0292-6152)ㄹ, Güven KAYA (Orcid: 0000-0001-9769-3023) ${ }^{2 *}$ \\ ${ }^{1}$ İstanbul Üniversitesi, Orman Fakültesi, İSTANBUL \\ ${ }^{2}$ İç Anadolu Ormancılık Araştırma Enstitüsü Müdürlüğü, ANKARA \\ "Sorumlu yazar/Corresponding author: guvenkaya@ogm.gov.tr, Geliş tarihi/Received: 19.04.2017, Kabul tarihi/Accepted: 09.06.2017
}

\section{$\ddot{O} \mathbf{z}$}

Orman alanlarında sıklıkla maden çıkarılmak istenmektedir. Bu istek, madencilik üretimini artırırken ormancılık üretimlerini azaltmaktadır. Refah ekonomisinin klasik sorunu olan, sektörler arası tahsis kararları, ülkemiz ormanc1lık uygulamaları içerisinde, arazi izin ve ağaçlandırma bedellerinin belirlenmesi sorunu şeklinde görülmektedir. Bu çalışmanın amac1, Orman Genel Müdürlüğünün (OGM) Orman Kanunu'nun 16'ncı maddesi gereği verdiği izinlerde talep ettiği bedelleri hesaplama yaklaşımı ile evrensel değer belirleme yöntemlerini karşılaştırmalı olarak irdelemektir. Bu amaçla, seçilen gerçek bir olayın verileri örnek alınarak OGM'nin ilgili yönetmeliğinin kabul ettiği değer hesapları yapılmıştır. Bu hesaplama yaklaşımı ile evrensel değer belirleme yaklaşımları karşılaştırılmış ve yönetmelikle ortaya konan yaklaşımın kısmen maliyetlere dayalı bir bakış içerdiği, pazar fiyatları, toplumsal tercihler ve transfer edilen faydalarla ilgilenmediği görülmüştür. Buna ek olarak, yönetmelikle ortaya konan yaklaşımın temel bileşenlerinin, bilimsel bulgular yerine idari kararlara dayalı olarak kurgulandığı saptanmıştır.

Anahtar Kelimeler: Değer belirleme, madencilik, arazi izin bedeli, ağaçlandırma bedeli.

\section{A comparative study on valuation techniques and accounting approach of land allocation rent in practice of Forest Law, Article 16}

\begin{abstract}
Forest areas are often allocated for mining. This allocation reduces the production of forest good and services while increasing mining production. Sectoral allocation decisions, a classical question in welfare economics, seem to be the problem of determining the land allowance and reforestation costs in forestry applications in Turkey. The purpose of this study is to comparatively discuss the universal valuation methods with the accounting approach of compensation payments demanded for mining permits granted by the General Directorate of Forestry (GDF) in accordance with the Article 16 of the Forest Law. For this purpose, the value calculations adopted by the related regulation of the GDF have been carried out by using a real case study data. This computing approach was compared with the universal valuation approaches and it was shown that the regulation based approach includes partly a cost-based view and does not take into account market prices, social preferences and benefits transferred. Additionally, it was found that the basic components of the regulatory approach were set out based on administrative decisions rather than scientific findings.
\end{abstract}

Key Words: Valuation, mining, land allocation rant, reforestation cost.

To cite this article (Atıf): OK K., KAYA G., 2017. Orman Kanunu'nun 16'ncı maddesi uygulamalarında alınan bedellerin hesaplanma yaklaşımının değer belirleme yöntemleriyle karşılaştırmalı irdelenmesi, Orman Genel Müdürlüğ̈ Ormancılık Araştırma Dergisi, 4(1):46-60 DOI: https://doi.org/10.17568/ogmoad.307117

\section{Giriș}

Orman-insan ilişkisinin köklerine inmek için yaşamın ortaya çıktığ 1 zamana kadar ilerlemek gerekir. Oysa madenler insanların ilgi alanına ormanlardan daha sonra girmiştir. İnsanın çevresini değiştirme girişimlerinin başlaması; kendi kültürünü yaratma yolunu açmış ve bu kapsamda aletler üretmek, kentler kurmak, daha iyi tarımsal, endüstriyel üretimler gerçekleştirmek için, yeni kaynaklar aranmıştır. İnsan, doğal gelişiminin gereği olarak ormanlarla ilişki içerisine girmişken, kültürel birikimler oluşmaya başladığında, madencilikle ilgilenmek zorunda kalmıştır.

Özellikle orta çağdan başlayan süreçle birlikte, orman ve maden kavramları sıklıkla birlikte anılmıştır. Pek çok maden kaynağı ormanların içerisinde bulunmuştur. Keşfedilen madenleri çıkarmak için ormanın yapısı değiştirilmiştir. Orman ürünle- 
ri bir araç veya kaynak olarak kullanılarak madencilik yapılabilmiştir. İnsanlığın gelişimiyle birlikte, tuz gibi madenlerin yaşamsal, kalay, demir gibi madencilik ürünlerinin ise kentsel yaşam ve savaş endüstrisi için önemi daha iyi anlaşılmış ve maden işletmeciliği, dünyanın her yerinde ve neredeyse her zaman desteklenmiştir. Gimpel'in (1996) belirtiğine göre; her zaman, hiç kimseden çekinmeden, başpiskoposların, manastır reislerinin ve kontların arazileri dahil, her yerde özgürce kalay cevheri kazıp çıkarmaya; eritmek için de, ormanlara zarar vermeksizin, çekiler halinde odun satın almaya, işletmelerinde yararlanmak üzere 1rmakların yataklarını değiştirmeye madencileri yetkili kılan yasalar 1201 yılında dahi var olmuştur. Maden çıkarma ve işletme izni verilen kişilere hem kamu hem özel ormanlardan yararlanma hakları tanınmıştır.

İlginçtir ki ülkemiz ormancılığının kökeninde de maden ve orman birlikteliği dikkat çekmektedir. Ormancılık ve madencilik işleri; 1872 ve 1878 yıllarında Orman ve Maden Bakanlığı, 1893-1908 döneminde ise Orman, Maden ve Tarım Bakanl1ğ1 altında ve birlikte yönetilmiştir (Gümüş, 2014). 1880-1893 y1lları arasında ise Orman ve Maden Mektebi (Gümüş, 2016) isimli bir okulda, ormancılar ve madenciler birlikte eğitilmiştir.

Ormanların sürekliliği yönündeki kaygıların artması, orman mal ve hizmetlerinin gittikçe kıtlaşması, insan kültürünün geleceği için gerek ve öneminin bir sorun olarak görülmesiyle birlikte, bu iki sektörün yollarının ayrılmaya başladığı düşünülebilir. Üzerinde hem maden hem orman olan bir arazide her iki ekonomik etkinliği birlikte yürütmek, sadece galeri işletmeciliği şeklinde yapılan madencilikte olanaklıyken, özellikle açık maden sahalarında bu iki kaynak kullanım şekli arasında ister istemez bir rekabet (rivalry) ortaya çıkmaktadır.

\subsection{Optimal kaynak tahsisi ve ormancılık}

Günümüz insanları ormanlardan tomruk, yakacak odun gibi ticari ürünler talep ederken, sellerden, çığlardan korunma, su rejimini iyileştirme gibi kamusal hizmetler de istemektedir. Üstelik günümüz insanının talebi, tomruk üretiminde olduğu gibi doğrudan veya sellerden koruma gibi dolaylı kullanım değerlerinin ötesine geçmiş, miras değeri, seçenek değeri, varlık değeri gibi tamamen kullanım dışı değerleri yahut pasif kullanım değerlerini kapsar bir hal almıştır. Biyolojik çeşitlilik, meraklı insanlar için bir rekreasyonel firsat oluşturup kullanım değeri taşırken, gelecek nesillerin de çeşitliliği görmesini isteyenler için miras değeri üretmekte, olası yeni iş alanları ile endüstri olanaklarını dü- şünenler için ise seçenek değeri yaratmaktadır.

$\mathrm{Bu}$ nedenle, günümüz toplumunda bir yeri orman olarak yönetmekten vazgeçmenin firsat (alternatif) maliyeti, geçmişin dünyasına göre çok daha fazladır ve daha ayrıntılı yöntemleri kullanmayı gerektirir. Bu nedenle, bir orman parçasının ormancılık dışı herhangi bir üretime tahsis edilmesi için, ormancılıkla üretilen tüm değerlerden daha fazla kamusal yararın üretilmesi ve bunun üzerinde uzlaşı sağlanmış yöntemlerle kanıtlanması gereklidir.

$\mathrm{Bu}$ yaklaşımla, günümüz dünyasında bir yeri orman olarak tutmak yerine, madencilik, zeytincilik, turizm, vb. ormancılık dışı bir üretime tahsis etmek isteyenlerin, alternatif kullanım biçimiyle üretilecek değerin, ormanc1lıkla üretilenden daha büyük olduğunu kanıtlaması gereklidir. Üstelik bu durum, ormancılığa özgü bir karar verme kuralı da değildir. İster ormancılık ister tarım ister turizm olsun, kıt bir arazinin bu sektörlerden herhangi birine tahsis edilebilmesi için, sıfır firsat maliyetinin oluşması refah ekonomisinin bir kuralıdır. Sıfır fırsat maliyetli bir sektörün seçilmesi, ancak ve ancak en büyük kamusal yararın üretildiği sektöre kaynağın tahsis edilmesiyle mümkündür.

Sektörler arası kaynak tahsisi konusunda yol gösterici bir ilke olarak Pareto optimum kaynak tahsisi anlayışından yararlanılabilir. Pareto'ya göre; arazi, sermaye veya emek şeklinde bulunan ve her zaman kıt olan kaynakların, alternatif kullanıcılara (bireyler veya ormancılık, madencilik vb. sektörler) tahsis şeklinin optimum olup olmadığına karar vermek için, kaynakların farklı kullanım biçimlerinin yarattığı etkileri bir bütün olarak ele almak gereklidir. Kaynak kullanım şekli değiştirildiğinde, en az bir kullanıcının durumu iyileşirken, diğer kullanıcıların durumları kötüleşmiyorsa, önerilen yeni kaynak kullanım şekli daha iyidir ve kullanım şeklini değiştirme kararı, kaynak tahsisini optimale yaklaştıran bir girişimdir (Kazgan, 1993).

Pareto optimalitesi yaklaşımı ormancılık- madencilik sektörleri arasındaki kaynak tahsisi konusuna uygulandığında (Demirbugan, 2015) madencilik sektörü iyileşirken, ormancılık sektörünün kötüleşmemesi veya madencilik ekonomiye katkı yapıyor diye, ormancılık alanında oluşan kayıpların görmezden gelinmemesi gerekir. Ülke ekonomisine madenlerin yaptığı katkıdan, ormanlarda oluşan kayıplar düşülmeli ve halen bir katkının oluşup oluşmadığına dikkat edilmelidir.

Diğer yandan ormanlık bir arazinin başkaca kullanımlara tahsis edilmesi nedeniyle ormancilıkta 
üretilen değerlerin üretiminden vazgeçmekle oluşan toplumsal kayıpların, ormancılık sektörüne ve topluma geri ödenmesi de gereklidir. Bunun için, bir ormanlık alanın başkaca kullanımlara tahsisi ile ortaya çıkan kayıplar hesaplanmalı, tahsis süresi boyunca katlanılan kayıplar, tahsisi alan kullanıcı tarafindan tazmin edilmelidir.

$\mathrm{Bu}$ gereklilik nedeniyle, bir orman arazisini bir başka kullanıma tahsis etmeden önce, değer belirleme çalışmalarının yapılması zorunludur. Üstelik olası istismarları önlemek ve her uygulamada adil bir inceleme yapılmasını sağlamak üzere, bu değer belirleme çalışmasının nasıl yapılacağının mevzuat içerisinde açıklanmış olması gereklidir. Ülkemiz mevzuatı incelendiğinde, sorunun sadece ormancilık sektöründe yaşanmadığ görülmektedir. Sektörler arası tahsisin ekonomik, sosyal ve ekolojik boyutlarının dengeli bir şekilde ele alınmadığı, hatta bazen görmezden gelindiği ortaya çıkmaktadır.

Ormancılık mevzuatı içerisinde bir inceleme yapıldığında, halen geçerli 6831 sayılı Orman Kanunu'nun 16'nc1, 17'nci ve 18'nci maddelerinin, ormancılık dışı kullanımlara yönelik hükümler içerdiği görülmektedir. Madencilik konusu özellikle 16'ncı maddede işlenmiştir. Üstelik bu madde kapsamında yapılacak inceleme ve uygulamaları daha ayrıntılı açıklamak üzere 18 Nisan 2014 tarih ve 28976 sayılı Resmî Gazete ile Orman Kanunu'nun 16'ncı Maddesinin Uygulama Yönetmeliği (OGM, 2014) çıkarılmış, 19 Nisan 2015'de bugünkü şekle dönüştürülmüştür. Bu makalede kısaca 16'nc1 Madde Uygulama Yönetmeliği olarak adlandırılan söz konusu yönetmelik öncesinde de, madencilik yapmak üzere orman arazisi tahsis edilenlerden; arazi izin bedeli, teminat bedeli ve ağaçlandırma bedeli adı altında ücretler alınmış ve bu ücretlerin belirlenme yaklaşımı Miraboğlu (1979) tarafından eleştirilmiştir. Ancak, madencilerin, Orman Genel Müdürlüğünün (OGM) bedelleri çok fazla artırdığ1 yönünde şikâyetlerde bulunduğu, konuyu mahkemelere götürerek, adli makamlar nezdinde tartışmayı halen sürdürdüğü görülmektedir.

Çalışmanın amacı, Orman Kanunu'nun 16'ncı maddesi uygulamalarına konu bir örnek olaydan hareketle, madencilik çalışmalarından ormancılık sektörü adına talep edilen bedellerin hesaplanma biçimini, çıkarılan uygulama yönetmeliği ve olası diğer değer belirleme yöntemleriyle karşılaştırmalı olarak irdelemek ve bilimsel değer belirleme yöntemleriyle ilişkisini tartışmaktır.

\subsection{Orman değerlerinin belirlenmesinde kullanılan evrensel yöntemler}

Gerçek dünyada Pareto optimum bir tahsisin oluşturulmasındaki güçlükler iktisatçıları kaybedenlerin kayıplarını kazananların tazmin ettiği, ikinci en iyi durumunu tanımlamaya itmiştir. Bu açıdan, ormanların madenciliğe tahsisi gibi çevresel kaynakların ve bu kaynakların sağladığı mal ve hizmetlerde nitelik ve nicelik olarak değişime yol açan kararların toplumun refahında yaratacağ 1 değişikliklerin, diğer bir deyişle ekonomik değerlerinin hesaplanması ve tahsis bedeli olarak tazmini gerekir. Refah değişimi ise, arz değişiminin iyileştirme veya kötüleşme olması durumuna ve bireylerin değişimi isteme veya engelleme çalışmalarına göre, kişilerin maksimum ödeme, minimum kabul eğilimiyle ölçülmektedir. Tüketici rantının farklı görünümleri olan bu ölçütler, refah değişiminin, dolayısıyla ekonomik değerin doğru ölçütleridir.

İkinci Dünya Savaşından sonra toplumun çevresel kaynaklara yönelik talebinin nitel ve nicel olarak değişimi, Amerika Birleşik Devletleri (ABD)'nden başlayarak çevresel değer belirleme yöntemlerinin gelişmesini sağlamıştır. Bu gelişimde ormanların ürettiği pazar fiyatı olmayan malların ekonomik değerinin ölçülmesine yönelik araştırmalar öncü rol oynamıştır. Günümüzde ormanların sunduğu mal ve hizmetlerin ekonomik değerini ölçmek için en yaygın kullanılan değer belirleme yöntemleri; pazar fiyatları, üretim fonksiyonu yaklaşımı, açıklanmış tercihler yaklaşımı, belirtilen tercihler yaklaşımı, maliyete dayanan yöntemler ve fayda transferi yöntemleri şeklinde sınıflandırılabilir.

Pazar fiyatları yöntemi, odun hammaddesi ve bazı odun dışı ürünler gibi alıcıların ödeme eğilimlerini pazar ortamına yansıttıkları ve etkin bir pazar fiyatı olan mal ve hizmetlerin değerlerinin belirlenmesi için kullanılmaktadır. Nitekim pazar fiyatlarını temel alarak, ormancılık sektöründe uzun yıllardan beri, ormanın ve orman arazisinin değeri (Firat ve Miraboğlu, 1962; Firat, 1967; Miraboğlu, 1979; Bekiroğlu, 2002) hesaplanmaktadır. Bu yaklaşımın maden tahsis veya zararlarının hesaplanmasında nasıl kullanılabileceğine odaklanmış Miraboğlu (1979) ve Şahin'in (1992) çalışmaları bulunmakta, Daşdemir (2011) ve Türker'in (2013) madenciliğe özel problem örneklerine yer verdiği görülmektedir.

Ancak, günümüz orman kaynaklarının sunduğu pek çok mal ve hizmetin, idari olarak saptanmış kullanım bedelleri olsa dahi, belirgin pazar fiyatı bulunmamaktadır. Örneğin, madencilik nedeniyle üretilemeyen orman ürünleri 
için pazar fiyatlarını değer ölçüsü olarak almak mümkünken, bozulan su rejimiyle oluşan kayıplar için bir pazar fiyatı bulmak olanaksızdır.

Üretim fonksiyonu yönteminde, ormanların sağladığ1 sel kontrolü, toprak koruma gibi hizmetlerin ekonomik değerini belirlemek için pazar fiyatı olan örneğin bir tarım ürününün üretimine yapılan katkı temel alınır. Bu yöntemi etkin kullanabilmek için ormanların ürettiği hizmetlerin ormancılık dışı malların üretimindeki etkisini sağlıklı yansıtan üretim fonksiyonlarına ihtiyaç vardır.

Açıklanmış tercihler yaklaşımına dahil olan seyahat maliyeti ve hedonik fiyatlandırma yöntemleri ise, değeri belirlenecek mal için vekil pazarları kullanır. Seyahat maliyeti yöntemi ulaşım pazarın1, hedonik fiyatlandırma yöntemi emlak piyasasını kullanarak değer belirler.

Seyahat maliyeti yöntemi, açık hava rekreasyonu talep ve ekonomik değerini tahmin yöntemidir. Yöntem, orman içi rekreasyon alanları için talep eğrisi türetirken, "bir rekreasyon alanına yapılan yıllık ziyaret sayısının bu ziyaretlerin seyahat maliyetleriyle ters orantılı olarak değiştiği" varsayımından hareket eder. Talep fonksiyonunda seyahat maliyetlerinde kuramsal artışlar karşısında oluşan ziyaret sayılarındaki değişimle tüketici rantı, dolayısıyla toplumun refahındaki değişimi yansitan ekonomik değer elde edilir (Kaya, 2002). $\mathrm{Bu}$ yöntemle, örneğin madencilik nedeniyle ormanların sağladığı rekreasyon hizmet değerindeki azalma tahmin edilebilmektedir. Nitekim, Kuzeydoğu Finlandiya Oulanka-Ruka'da milli park ve çevresinin rekreasyonel kullanım değerinde madencilikten kaynaklanan değişim seyahat maliyeti yöntemiyle tahmin edilmiştir. Araştırmada farklı madencilik senaryolarına göre ormanlara ziyaretlerin \%29-80 arasında azalacağı, ziyaretçi başına refah kaybının ise 196-577 € arasında olacağı belirlenmiştir (Kosenius ve Horne, 2016).

Hedonik fiyatlandırma yöntemi, konut gibi birleşik malların nitelikler demetinden oluştuğunu, bu niteliklerden birinin çevresel nitelik (orman manzarası, ormana yakınlık) olduğu düşüncesinden hareket eder. Eğer yerleşim yerlerinde konutlar arasında yeteri kadar nitelik-fiyat varyasyonu mevcutsa, ilgili niteliğin (manzara) örtük fiyatı bu ilişkiden yararlanarak elde edilen hedonik fiyat fonksiyonu ile belirlenebilir (Kaya ve Özyürek, 2015). Örneğin, ABD'de 12 eyalette gerçekleştirilen bir hedonik fiyat uygulamasında (Williams, 2011) ek bir açık kömür madeninin yerleşim alanlarında emlak değerini \%0,34-1,7 arasında azaltıcı etki yaptı- ğ1, ortalama bir yerleşimde refah kaybının 40,15 milyon \$'a ulaştığı tahmin edilmiştir. Türkiye'de bir araștırmada (Kaya ve Özyürek, 2015), ODTÜ Ormanı manzarasının ekonomik değeri, farklı niteliklere göre ve hedonik fiyatlandırma yöntemiyle, yıllık 4,31-6,47 milyon $\$$ arasında tahmin edilmiştir. Bu da ormanın madencilik, yerleşim vb. diğer amaçlara tahsisi halinde sadece manzara açısından mahrum kalınacak faydanın büyüklüğüne işaret etmektedir.

Belirtilen tercihler yaklaşımı ise, bireylerin bir çevresel değişim için ödeme/kabul eğilimlerini herhangi bir pazar ortamında açıklamadıklarında, tercihlerinin kuramsal pazarlar eşliğinde sorgulanması düşüncesine dayanır. Koşullu değer belirleme ve seçim modelleme yöntemlerini içeren bu yaklaŞım, kuramsal pazar ortamı kullanıldığ 1 için hem kullanım hem kullanım dışı değerleri sorgulama yeteneğine sahiptir.

Koşullu değer belirleme (KDB), çevresel kaynaklarda meydana gelen iyileşme ve kötüleşmeler için bireylerin ödeme veya kabul eğilimlerini kuramsal senaryo eşliğinde doğrudan sorgulayarak öğrenmeye dayanan, bu şekilde çevresel kaynak kullanımları sonucu toplumsal refahta meydana gelen değişimleri belirlemeye çalışan bir çevresel değer belirleme yöntemidir (Kaya, 2002). Ormanların madenciliğe tahsisi ile ilgili en bilinen koşullu değer belirleme çalışması, Avustralya Kakadu Koruma Zonunda gerçekleştirilmiştir. Araştırmada Kakadu'yu korumanın değeri koşullu değer belirleme yöntemiyle 435 milyon Avus. \$ olarak tahmin edilmiş, bu değer madenciliğe tahsis halinde yaratılacak 102 milyon Avus. \$’1 değerin üzerinde olduğu için, alanın koruma statüsünün devamına karar verilmiştir (Carson vd., 1994). Portekiz'de gerçekleştirilen ve orman yönetim seçeneklerinin ekonomik değerinin araştırıldığı bir koşullu değer belirleme çalışmasında da madenciliğe tahsis içermeyen seçeneklerin ekonomik değerinin daha yüksek olduğu görülmüştür (Madureira vd., 2011).

Seçim modelleme, ormanlar gibi bir çevresel kaynağın niteliklerindeki değişimin değerini, bireylere farklı nitelik (çıktı) seviyeleri ve bu seviyeler için ödeme/kabul eğilimleri, çeşitli senaryolar şeklinde verildiğinde, kişilerin tercihlerinden türetmeye çalışan bir yöntem grubudur (Kaya, 2002). Bu yöntem grubu içindeki yöntemler, seçeneklerden birinin seçilmesi, oranlanması, sıralanması veya ikili karşılaştırılmasının istenmesine göre seçim deneyleri (koşullu seçim), koşullu sıralama, koşullu oranlama ve ikili karşılaştırma 
yöntemi olarak adlandırılır. Seçim deneyleri yöntemiyle Avustralya New South Wales'de açık kömür madenlerinin (Gillespie and Bennett, 2012) ve Avustralya Surat Havzasında tarım arazilerinin madenciliğe tahsisinin (Windle ve Rolfe, 2014) çevresel etkilerinin, Kanada'da NorSask Orman1 (Shapansky vd., 2003), İspanya'da ormanların bazı faydalarının (Brey vd., 2007) ve mantar meşesi ağaçlandırmalarının faydalarının (Oviedo vd., 2006) ekonomik değeri tahmin edilmiştir. Türkiye'de gerçekleştirilen bir seçim deneyleri araştırmasında ise (Deniz ve Ok, 2016) bir erozyon kontrol projesinin sel riskinin ertelenmesi, toprak erozyonunun önlenmesi, baraj ömrünün uzatılması ve kaliteli kaynak suyuna erişimin artırılması gibi faydalarının ekonomik değerleri tahmin edilmiştir.

Diğer bir ekonomik değer belirleme yöntem grubu, sakınılan maliyetler, yerine koyma/restorasyon harcamaları yöntemi gibi yöntemleri içeren ve esasen maliyete dayalı yöntemlerden oluşur. $\mathrm{Bu}$ gruba giren yöntemlerde; ormanların ürettiği hizmetlerle oluşması önlenen zararların yaratacağ1 toplam maliyet, değer ölçüsü olarak alınır. Fakat yöntemin bu zararları önlemek için alınabilecek ormancılık dışı önlemlerin toplam maliyetini veya zarar gerçekleştiğinde ortaya çıkan kayıpları onarmanın maliyetlerini değer ölçüsü olarak alan uygulamaları da bulunmaktadır. Dickie (2003)'e göre, bir çevresel zarardan sakınmak için katlanılan maliyetler, zarara davranışsal bir tepki içerdiğinden, bireylerin tercihlerini de bir ölçüde yansıtmaktadır ve refah değişimini yansitabilir. Buna karşın, yerine koyma harcamaları zarara karşı davranışsal herhangi bir tepki içermediğinden bireylerin tercihlerinin göstergesi değildir. Bu tür maliyet ölçütleri, ancak katlanıld1ğında veya katlanılması planlandığında ekonomik değerin minimum ölçüsü olarak kabul görebilir.

Sakınılan maliyet yöntemi özellikle toplam orman değeri araştırmalarında (Bann ve Clemens, 2001; Türker vd., 2005; Wilson, 2014), karbon tutma hizmetinin, karbonun sosyal maliyetinin ve su kalitesinin iyileştirilmesi hizmetinin değeri için su arıtma maliyetlerinin saptanmasında kullanılmıştır. Yerine koyma harcamaları yöntemine örnek olarak, toprak koruma hizmetinin ekonomik değeri, toprak besin maddeleri için yapay gübre maliyetlerinin belirlenmesi çalışmaları gösterilebilir. Keza restorasyon harcamaları yöntemine madencilik sonrası ekosistem 1slahı için katlanılan tüm maliyetlerin hesaplanması örnek verilebilir.

Fayda transferi yöntemi, diğer yöntemlerle tahmin edilen değer fonksiyonunun zaman ve mekân olarak başka değer belirleme çalışmaları için geçerli kabul edilmesidir. Sağlıklı değer transferi için günümüzde geçerli ve güvenilir değer tahminleri üreten araştırmalarda türetilen fonksiyonlardan yararlanarak olgu analizlerine imkân veren veri tabanları kurulmaktadır. Örneğin, Mazzotta vd. (2015), ABD West Virginia'da açık maden ocakları nedeniyle rekreasyonel olta balıkçılarının kayıplarını, açıklanmış ve belirtilen tercihler yöntemleriyle gerçekleştirilen 19 araştırma ve 108 gözlemle üretilen değer tahminleri ve açıklayıcı değişkenlerden yararlanarak olgu analizi ile tahmin etmiştir.

\section{Materyal ve Yöntem}

Çalışmanın amacına uyan bir değerlendirme yapabilmek için mantıksal bir sürecin izlenmesi zorunludur. Bu süreç içerisinde, araştırmada öncelikle, gerçek bir olaydan yola çıkarak 16'ncı Madde Uygulama Yönetmeliği’nin tanımladığı şekilde tahsis bedellerinin hesaplanma şekli, örnek çözümler yapılarak açıklanmaktadır. Hesaplama örnekleri 2016 yılı temel alınarak yapılmıştır. Hesaplamaların ardından, yukarıda tanıtılan ve günümüz ormanlarının oluşturduğu kullanım ve kullanım dışı değerlerin saptanmasında kullanılan evrensel değer belirleme yöntemleri ile OGM tarafından yönetmelikle ortaya konan hesaplama yöntemi karşılaştırılmakta, uyum ve uygunluk irdelemesi yapılmakta, boşluklar belirlenmektedir. Çalışma sonunda ormanların ormancılık dışı kullanımlara tahsis olaylarında daha az tartışılır bir yaklaşım oluşturulabilmesine yönelik öneriler getirilmektedir.

Araştırma verileri gerçek bir olaydan elde edilmişse de bu olayda adı geçen kişi ve kurumların ticari ve idari hak ve sorumlulukları dikkate alınarak, isimlerin kullanılması tercih edilmemiştir. Esasen çalışmanın amacı bu örnek olaydaki durumu tartışmaktan çok, benzer tahsis olaylarındaki hesaplama yaklaşımlarını irdelemek olduğundan, firma veya ilgili orman işletme müdürlüklerinin adlarının bilinmesi gerekli değildir. Araştırmada yapılan irdelemeler incelenen örnek olaydan hareketle ve 16'nc1 Madde Uygulama Yönetmeliği kapsamında yapıldığg için, tek bir örnek olay üzerinden hareket etmek gibi bir sakınca taşımamakta, bugün izin verilen tüm benzer olayları temsil etmektedir.

\section{1. Örnek olaydaki değer belirleme problemin temel verileri}

Araştırmada verileri incelenen ruhsat sahibi madencilik şirketi X, Orman Bölge Müdürlüğü ormanlarından maden çıkarmaktadır. Ruhsat sahibi 
olduğu orman alanının işlettiği kısmı, madencilik çalışmalarına paralel olarak farklılaşabilmektedir. Nitekim GG.AA.YYYY tarihinde, Orman ve Su İşleri Bakanlığının X sayılı oluru ile toplam 162.718,00 $\mathrm{m}^{2}$ ormanda, GG.AA.YYYY tarihine kadar madencilik yapma izni almıştır. İzin talebinde ormanın 131.746,00 $\mathrm{m}^{2}$ bölümünü açık işletme alanı olarak kullanacağını belirtirken, geri kalan kısımları yıkama eleme tesisi $\left(4.550 \mathrm{~m}^{2}\right)$, çökertme havuzu $\left(1.200 \mathrm{~m}^{2}\right)$, şantiye tesisi (7.819 $\left.\mathrm{m}^{2}\right)$, stok alanı $\left(12.000 \mathrm{~m}^{2}\right)$ ve pasa döküm alanı $\left(5.403 \mathrm{~m}^{2}\right)$ olarak kullanacağını bildirmiştir. Bu alana ek olarak, GG.AG.YYYY tarihinde $Z$ ve T sayılı iki ayrı olurla, enerji nakil hattı (ENH) $\left(24.258,00 \mathrm{~m}^{2}\right)$ ve yol $\left(26.321,65 \mathrm{~m}^{2}\right)$ yapımı için ek orman alanı talep etmiş ve tahsis yapılmıştır. $\mathrm{Bu}$ tahsislerle birlikte madencilik amaçlı kullanı- ma verilen orman alanı 213.297,65 $\mathrm{m}^{2}$ olmuştur.

Zaman içerisinde, madencilik işletmesinin kendisine tahsis edilen orman alanına ek alanlar katmak üzere yeni başvurular yaptığı, daha önce tahsis edilmiş bazı alanları amaç değiştirmeksizin süre uzatarak (temdit) kullanırken, bazı yerlerde ise kullanım amacını değiştirdiği görülmektedir. Bu durum arazi izin bedeli hesaplanmasında etkili olduğundan, idarece yeniden hazırlanan Y ve N sayı11 olurlarla belgelenmiştir.

Tablo 1'de ağaçlandırma, arazi izin ve teminat bedeli hesaplanması gereken madencilik işletmesinin fiili arazi kullanım şekli gösterilmiştir. Tablo 1'den görüldüğü gibi, ruhsat sahibi ve işletme aynı kalsa da zaman içerisinde kullanılan ormanın alanı ve amacı sürekli değişerek 387.886,58 $\mathrm{m}^{2}$ düzeyine çıkmıştır.

Tablo 1. Madencilik için tahsis edilen orman alanının güncel kullanım şekli Table 1. Actual land use of forest area allocated for mining

\begin{tabular}{lrl}
\hline Tahsis Amaçları & Alanı $\left(\mathrm{m}^{2}\right)$ & İ̧̧lemler ve Açıklamalar \\
\hline Açık maden işletme alanı & $113.084,00$ & Olur Y ile devam-temdit \\
Toprak depolama alanı & $8.487,00$ & Olur Y ile $131.746 \mathrm{~m}^{2}$ açık işletmeden amaç değişimi \\
Kantar & $1.495,00$ & Olur Y ile $131.746 \mathrm{~m}^{2}$ açı işletmeden amaç değişimi \\
Y1kama eleme tesisi & $8.680,00$ & Olur Y ile $131.746 \mathrm{~m}^{2}$ açık işletmeden amaç değişimi \\
Y1kama eleme tesisi & $5.750,00$ & Olur Y ile yıkama ve çökertme havuzundan amaç değişimi \\
Y1kama eleme tesisi & $5.403,00$ & Olur Y ile 5.403 m² pasa dökümden amaç değişimi \\
Şantiye tesisi & $7.819,00$ & Olur Y ile devam-temdit \\
Stok alanı & $12.000,00$ & Olur Y ile göre devam-temdit \\
Yol & $26.771,65$ & Olur Z ve T ile devam-temdit \\
ENH & $24.258,00$ & Olur Y ile T ile devam - temdit \\
Açık maden işletme alanı & $168.624,33$ & Yeni talep \\
Y1kama eleme tesisi & $5.514,60$ & Yeni talep \\
\hline N Sayılı Olur Toplamı & $387.886,58$ & \\
\hline
\end{tabular}

$\mathrm{Bu}$ madencilik işletmesinden geçmiş yıllarda idarece alınan arazi izin bedelleri Şekil 1'de gösterilmiştir. Şekil 1'den görüldügü gibi, firma açık maden alanı veya tesis alanı olarak kullandığ ormanlara 16'ncı Madde Uygulama Yönetmeliği’nin kabul edildiği 2014 yılı Nisan ayı öncesinde 0,72-0,89 $\mathrm{TL} / \mathrm{m}^{2}$ arasında değişen arazi izin bedeli ödemiştir. Bir başka değişle, ormanın madenciliğe verilmesiyle oluşan kayıpları telafi etmek üzere, bu bedel talep edilmiştir. Yönetmelik'in yayınlandığ1 2014 yilından sonra bu bedel 7,49 TL/m² ye kadar çıkmıştır.

Arazi kullanım bedellerindeki bu artış, firmalarla OGM arasında adli davalarla kanıtlanan bir çatışma alanı oluşturmuştur. Yönetmelik'in 2015'de gördüğü değişikliğin ardından, Şekil 1'den görüldüğü gibi birim bedelde bir azalma olmuştur.

\subsection{6'ncı madde uygulama yönetmeliği'nin he-} saplama yaklaşımı ve örnek uygulama

Şüphesiz 16'ncı Madde Uygulama Yönetmeliği öncesi dönemlerde arazi izin bedellerinin hesaplanma yaklaşımı da Miraboğlu (1979) veya Şahin'in (1992) yaptığı gibi, sorgulanmaya muhtaçtır. Ancak, bugünün konusu geçmiş hesaplama yaklaşımı değil, geçerli anlayıştır. Bu nedenle, 16'ncı Madde Uygulama Yönetmeliği incelenmiş ve uygulanması istenen hesaplama yönteminin ana hatları aşağıda açıklanmıştır. Yönetmeliğe göre; işletme sahiplerinden Ağaçlandırma Bedeli, Arazi İzin Bedeli, Teminat Bedeli ve Ek Devlet Hakkı adı altında farklı bedeller hesaplanarak tahsil edilmektedir. Ek Devlet Hakkı yönetmelikte, Maden Kanunu'na atıf yaparak hesaplandığı için, bu araştırmanın kapsamı dişında tutulmuştur. 


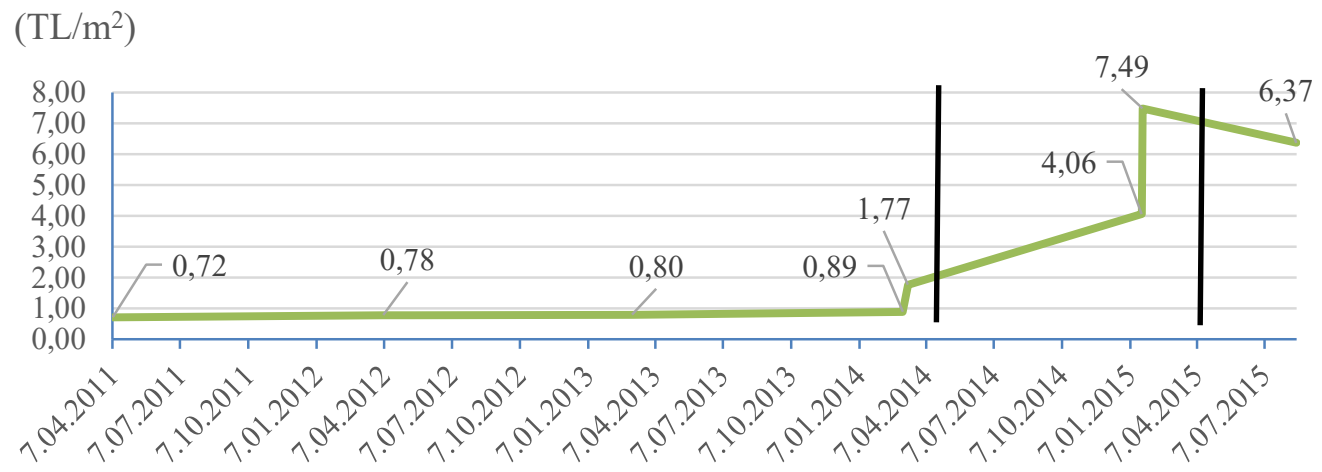

Şekil 1. Örnek maden alanı için OGM tarafından alınan arazi izin bedellerinin değişimi Figure 1. Trend of the rent for forest area allocated for mining

\subsubsection{A ğaçlandırma bedelinin hesaplanması}

16'ncı Madde Uygulama Yönetmeliği'nin 20'nci maddesi 1'nci fikrası (a) bendine göre; Ağaçlandırma bedeli Genel müdürlükçe Asgari Ücret Tespit Komisyonu tarafından yılın ikinci yarısı için tespit edilen 16 yaşını doldurmuş işçilerin bir günlük normal çalışma karşılı̆̆ 1 asgari ücretlerinin 294 gün/ hektar katsayısıyla çarpımı sonucu belirlenen ağaçlandırma birim hektar bedelinin izin alanı ile çarpımı sonucu alınacak bedeldir. Madencilik nedeniyle orman niteliğini kaybeden yerin bir defa ağaçland1rılmasının yeterli olacağı varsayılarak, ağaçlandırma bedeli tahsis edilen yer için bir kez alınmakta, yeni tahsislerle eklenen yeni yerler oluştuğunda, yeni ağaçlandırma bedelleri hesaplanmaktadır. İncelenen örnek olayda, 2016 yılı itibariyle ağaçlandırma bedeli alınmamış orman alanının 174.138,93 $\mathrm{m}^{2}$ olduğu görülmüştür.

OGM'nin 18.01.2016 tarih, 95735 say1 ve "2016 y1l birim bedelleri” konulu talimatında, “.. 2016 yıl içinde orman alanlarında verilecek izinlerde bedeller hesap edilirken kullanilacak olan birim bedeller; Ağaçlandırma bedeli: 16.140,60 TL/ha, Ağaçlandırılan alanların yıllık bakım bedeli: 1.100,00 TL/ha" olarak tespit edilmiştir. Yönetmelik ve OGM talimatında belirtilen birim ağaçlandırma bedeli ise $1,61406 \mathrm{TL} / \mathrm{m}^{2}$ 'dir.

Buraya kadar yapılan açıklamalar dikkate alınarak ve örnek olay verileri kullanılarak ağaçlandırma bedeli hesaplanmak istendiğinde; $A L A N_{t}$, ağaçlan- dırma bedeli alınacak tahsis alanı ve $B A B$, birim ağaçlandırma bedeli olmak üzere;

Ağaçlandırma bedeli $=A L A N_{i} \times B A B$

$$
\begin{aligned}
& =174.138,93 \mathrm{~m}^{2} \times 1,61406 \mathrm{TL} / \mathrm{m}^{2} \\
& =281.070,68 \mathrm{TL} \text { olarak bulunur. }
\end{aligned}
$$

\subsubsection{Arazi izin bedelinin hesaplanması}

Arazi izin bedelinin nasıl hesaplanacağ 1 ise 16 'nc1 Madde Uygulama Yönetmeliği'nin 20'nci maddesi 1'nci fikrası (b) bendinde açıklanmıştır. Bu bende göre "İzin alanının metrekaresi, cari yıl ağaçlandırma birim metrekare bedeli, bu Yönetmelik'in ekinde yer alan izin türü katsayıs Ek-1, ekolojik denge katsayısı Ek-2 ve il katsayısının Ek-3 çarpımlarının sonucu alınarak" arazi izin bedeli hesaplanmalıdır. Yönetmelikte atıf yapılan Ek 1, Ek 2 ve Ek 3'ün içerikleri sırasıyla Tablo 2, 3 ve 4'de verilmiştir.

Yönetmelik hükmü dikkate alındığında OGM'nin;

Arazi izin bedeli $=f$ (izin alanı, ağaçlandırma birim bedeli, izin türü, ekolojik denge, iznin verildiğ i il)

şeklinde bir değer fonksiyonunu kabul ettiği görülmektedir. Bir başka değişle, OGM’ye göre, bir maden işletmesine izin vermekle kaybedilen yıllık değerleri telafi etmek için izin verilen alan büyüklüğünü, o yıl geçerli ağaçlandırma bedelini, yapılmak istenen madencilik şeklini, izin verilen ormanın yapısıyla temsil edilen ekolojik dengeyi ve izin talep edilen yerin ülkenin neresinde olduğunu bilmek gerekli ve yeterlidir.

Tablo 2. Yönetmeliğe göre arazi izin bedeli hesaplarında farklı izin türleri için kullanılması gereken katsayılar Table 2. Coefficients that needs to be used for different aims of mining in the regulation

\begin{tabular}{lc}
\hline İzin Türleri & Uygulanması Gereken Katsayısılar $\left(\mathrm{k}_{\mathrm{izziir}}\right)$ \\
\hline Sondaj usulü maden arama izinleri & 0,2 \\
Maden arama, işletme ve hammadde üretim izinleri & 0,4 \\
Maden tesis ve altyapı tesis izinleri & 0,5 \\
Toprak dolgu izinleri & 1,5 \\
\hline
\end{tabular}


Tablo 3. Yönetmeliğe göre ekolojik denge katsayıları

Table 3. Coefficients on ecological balance in the regulation

\begin{tabular}{lc}
\hline Orman Amenajman Planlarına Göre Orman Durumu & $\begin{array}{c}\text { Ekolojik Denge } \\
\text { Katsayısı } \\
\left(\mathrm{k}_{\mathrm{ek0}}\right)\end{array}$ \\
\hline Ağaçsız alanlar & 1 \\
$\% 10$ 'dan daha az kapalı ormanlar ve kapalılığına bakılmaksızın Mak rumuzlu alanlar & 1,1 \\
$\% 11-40$ kapalı ormanlar & 1,4 \\
$\% 41-70$ kapalı ormanlar & 1,7 \\
$\% 71$ ve üstü kapalı ormanlar ve ağaçlandırma sahaları & 2 \\
\hline
\end{tabular}

Bununla birlikte, izin alanı konusunda yönetmelikte ifade edilen bir 5 ha istisnası bulunmaktadır. Uygulama Yönetmeliği'nin 8'nci maddesinin 2'nci fikrasında "Ancak aynı ruhsat alanı içinde maden işletme, aramada işletme amacılla bu Yönetmelik'in yayım tarihinden önce veya sonra iptal edilmiş olanlar da dahil Bakanlıkça verilmiş izin alanlarının toplamının beş hektara kadar olan kıs$m$ için arazi izin bedeli alınmaz, ek devlet hakkı alınır" ifadesi yer almaktadır.
Arazi izin bedeli fonksiyonunun uygunluğunu kararlaştırabilmek için, özellikle izin türü, ekolojik denge ve il katsayısı değişkenlerini daha yakından incelemek gereklidir. Tablo 2'den de görüldüğü gibi, tahsis edilen orman alanı, örneğin maden işletme alanı olarak kullanılacaksa, arazi izin bedeli hesaplanırken, birim alan miktarının 0,4 katsayıs1 ile çarpılması gereklidir. Benzer şekilde, orman alanı bir maden altyapı tesisi olarak kullanılacaksa, tahsis edilen alan 0,5 katsayısıyla çarpılarak, arazi izin bedeli hesaplanmalıdır.

Tablo 4. Yönetmeliğe göre arazi izin bedeli hesaplarında il katsayıları

Table 4. Coefficients used for different provinces in the regulation

\begin{tabular}{lc}
\hline İl Adı & $\begin{array}{c}\text { Katsayısı } \\
\left(\mathrm{k}_{\mathrm{i}}\right)\end{array}$ \\
\hline İstanbul & 3 \\
İzmir, Kocaeli & 2,8 \\
Adana, Ankara, Antalya, Aydın, Balıkesir, Bursa, Çanakkale, Mersin, Muğla, Osmaniye, Sakarya, & 2,4 \\
Samsun, Yalova, & 2 \\
Bartın, Bilecik, Bolu, Düzce, Edirne, Gaziantep, Giresun, Karabük, Kayseri, Kırıkkale, Kırklareli, \\
Konya, Kütahya, Ordu, Rize, Zonguldak, Denizli, Eskişehir, Hatay, Manisa, Tekirdağ, Trabzon \\
Adıyaman, Artvin, Afyonkarahisar, Amasya, Burdur, Çankırı, Çorum, Diyarbakır, Elazı̆̆, Erzincan, \\
Erzurum, Isparta, Kahramanmaraş, Kastamonu, Kırşehir, Kilis, Malatya, Nevşehir, Niğde, Sinop, \\
Sivas, Şanlıurfa, Tokat, Uşak, Yozgat \\
Aksaray, Bayburt, Gümüşhane, Karaman, Ağrı, Ardahan, Batman, Bingöl, Bitlis, Hakkâri, Iğdır, \\
Kars, Mardin, Muş, Siirt, Şırnak, Tunceli, Van
\end{tabular}

Arazi izin bedellerinin hesabını etkileyen bir diğer değişken Tablo 3'de gösterilen ekolojik denge katsayısıdır. Bu katsayının ormanın sadece kapalılığ 1 na göre oluşturulduğu görülmektedir. Tablo 3'deki kapalılık durumlarını ya ormanda ölçüm yaparak ya da amenajman planlarının meşcere haritalarından belirlemek gereklidir.

Uygulama Yönetmeliği’ne göre, madencilik iznine konu yerin ülkenin farklı illerinde aynı şekilde ele alınması doğru değildir. Bu nedenle, yönetmelikte iller farklı katsayılarla kümelenmiştir (Tablo4).
Buna göre, örneğin Bolu'daki bir madenin izin bedelini hesaplarken 2, İstanbul'da ise 3 katsayısı kullanılmalıdır. OGM'nin oluşturduğu il katsayıları aslında İstanbul ormanlarını madene tahsis etmenin, Bolu'da yapılan tahsise göre daha fazla kayba neden olduğu varsayımına dayanmaktadır.

Buraya kadar yapılan açıklamaları dikkate alarak ve bir örnek olarak Tablo 1'de 5.403,00 m² alana sahip yıkama eleme tesisi yapılmak istenen orman parçası $\left(\mathrm{ALAN}_{\mathrm{i}}\right)$ için alınması gereken arazi izin bedeli hesaplandığında, öncelikle yıkama tesisinin 
Tablo 2'de gösterilen izin türlerinden $\left(\mathrm{k}_{\mathrm{iztüu}}\right)$ hangisine girdiğine karar vermek gerekmektedir. Ardından, yıkama tesisi yapılacak orman parçasının Tablo 3'te gösterilen hangi ekolojik denge katsay1sıyla $\left(\mathrm{k}_{\text {eko }}\right)$ hesaba katılacağının kararlaştırılması zorunludur. Tablo 4'den iznin istendiği ilin katsayısı $\left(\mathrm{k}_{\mathrm{il}}\right)$ alındığında hesaplama için gerekli veriler tamamlanmış olmaktadır. Yıkama eleme tesisinin madencilik açısından maden tesis ve altyapı tesis izinlerine girdiği ve 0,5 katsayısının alınması gerektiği, ilgili arazi çalışması veya orman meşcere haritalarından bu yerin \%11-40 kapalı ormanlara denk geldiği ve 1,4 ekolojik denge katsayının uygun olduğu ve izin sahasının İstanbul il sınırları içerisinde kaldığı ve 3 katsayısı ile işlem görmesi gerektiği kabul edildiğinde;

$$
\begin{aligned}
& \text { Arazi tahsis bedeli }=A L A N_{i} \times \mathrm{BAB} \times \mathrm{k}_{i z t u ̈ r} \times \mathrm{k}_{e k o} \times \mathrm{k}_{i l} \\
&= 5403 \times 1,61406 \times 0,5 \times 1,4 \times 3 \\
&= 18.313,61 T L \text { olarak hesaplanir. }
\end{aligned}
$$

Ancak, bu bedel 5 ha istisnasının indirilmemiş halidir. Tablo 5'in 7. satırında, 5 ha istisnasının diger tahsis alanlarının toplam alan içerisindeki payı dikkate alınarak düşülmesiyle bulunan izin bedeli (15.952,92 TL) gösterilmiştir.

\subsubsection{Arazi amaç değişimi ve süre uzatımı durumlarında bedel hesabı örnekleri}

Tablo 5 incelendiğinde işlem (I*) isimli bir sütun içerdiği ve burada temdit (T) veya yeni (Y) ifadelerinin yer aldığı görülmektedir. Temdit, aynı amaçla daha önceki yıl kullanılmış ve süre uzatımı yapılan bir araziyi işaret ederken, yeni kelimesi ilk defa bedel hesabı yapılacak ormanı göstermektedir.

Yönetmelikte açıkça ifade edilmese de, farklı kullanım amaçları için farklı izin türü katsayıları oluşturulduğundan, aslında amaç değiştiğinde bedel hesabının değiştirilmek istendiği görülmektedir. Katsayı farklılı̆̆ından anlaşılmaktadır ki, bir olur ile tahsis yapılmış bir yerin kullanım amacı değişiyorsa, eski amaca göre belirlenmiş bedellerin yeni kullanım amacına göre güncellenmesi zorunludur. $\mathrm{Bu}$ güncellemenin yapılmaması halinde, maden tesis, altyapı tesis amaçlarından maden arama, işletme hammadde üretim amaçlarına doğru bir değişim, tahsis sahibinin daha fazla bedel ödemesine neden olur. Benzer şekilde, tahsis amacının maden işletme, arama, hammadde üretimden altyapı tesis, toprak dolgu gibi amaçlara değişmesi halinde, bir bedel güncellemesi yapılmazsa, kamu zararı oluşur. Bu nedenle, eski tahsis amaçlarının değiştiği

\begin{tabular}{|c|c|c|c|c|c|c|c|c|c|}
\hline Tahsis amacı & $\dot{I}^{*}$ & $\begin{array}{l}\operatorname{ALAN}_{\mathrm{i}} \\
\left(\mathrm{m}^{2}\right)\end{array}$ & $\begin{array}{c}5 \text { ha } \\
\text { indirimi } \\
\left(\mathrm{m}^{2}\right)\end{array}$ & $\begin{array}{c}\text { Bedele } \\
\text { konunalan } \\
\left(\mathrm{m}^{2}\right)\end{array}$ & $\begin{array}{l}\text { Ağaçlan. } \\
\text { bedeli } \\
\left(\mathrm{TL} / \mathrm{m}^{2}\right)\end{array}$ & $\mathrm{k}_{\mathrm{iztür}}$ & $\mathrm{k}_{\mathrm{eko}}$ & $\mathrm{k}_{\mathrm{il}}$ & Tutar (TL) \\
\hline Altyap1 tes. (Stok) & $\mathrm{T}$ & $12.000,00$ & $1.546,84$ & $10.453,16$ & - & - & - & - & $82.789,00$ \\
\hline Altyap1 tes. (Şantiye) & $\mathrm{T}$ & $7.819,00$ & $1.007,90$ & $6.811,10$ & - & - & - & - & $53.943,93$ \\
\hline YOL ve ENH & $\mathrm{T}$ & $26.771,65$ & $3.450,96$ & $23.320,69$ & - & - & - & - & $184.699,84$ \\
\hline YOL ve ENH & $\mathrm{T}$ & $24.258,00$ & $3.126,94$ & $21.131,06$ & - & - & - & - & $167.357,96$ \\
\hline Açık işl alanı & $\mathrm{T}$ & $113.084,00$ & $14.576,94$ & $98.507,06$ & - & - & - & - & $544.744,04$ \\
\hline Tesis Sahas1 & $\mathrm{Y}$ & $5.403,00$ & 696,47 & $4.706,53$ & 1,61 & 0,5 & 1,4 & 3 & $15.952,92$ \\
\hline Tesis Sahas1 & $\mathrm{Y}$ & $5.750,00$ & 741,20 & $5.008,80$ & 1,61 & 0,5 & 2 & 3 & $24.253,53$ \\
\hline Tesis Sahas 1 & $\mathrm{Y}$ & $5.514,60$ & 710,85 & $4.803,75$ & 1,61 & 0,5 & 2 & 3 & $23.260,61$ \\
\hline Tesis Sahas 1 & $\mathrm{Y}$ & $8.680,00$ & $1.118,88$ & $7.561,12$ & 1,61 & 0,5 & 1 & 3 & $18.306,14$ \\
\hline Altyap1 tesis & $\mathrm{Y}$ & $8.487,00$ & $1.094,01$ & $7.392,99$ & 1,61 & 0,5 & 2 & 3 & $35.798,21$ \\
\hline Açık işl alanı A & $\mathrm{Y}$ & $96.813,56$ & $12.479,62$ & $84.333,94$ & 1,61 & 0,4 & 2 & 3 & $326.688,09$ \\
\hline Kantar alan1 & $\mathrm{Y}$ & $1.495,00$ & 192,71 & $1.302,29$ & 1,61 & 0,5 & 1 & 3 & $3.152,96$ \\
\hline Açık işl. B alanı & $\mathrm{Y}$ & $71.810,77$ & $9.256,67$ & $62.554,10$ & 1,61 & 0,4 & 2 & 3 & $242.318,57$ \\
\hline Arazi izin Bedeli & & $387.886,58$ & $50.000,00$ & $337.886,58$ & & & & & $1.723 .265,78$ \\
\hline $\begin{array}{l}\text { Ağaçlandırma } \\
\text { Bedeli }\end{array}$ & & $174.138,93$ & & & 1,61 & & & & $281.070,68$ \\
\hline Hesaplanaı & 11 & nat Bedeli & $62.607,22$ & Ağaç & andirma ve & Arazi & izin $\mathrm{E}$ & edel & $2.004 .336,46$ \\
\hline
\end{tabular}

Tablo 5. Örnek olay için hesaplanan ağaçlandırma, arazi izin ve teminat bedelleri Table 5. Computed reforestation, cost land rent, and contract bond for case

*İ: İşlem; T: Temdit; Y: Yeni 
durumlarda yeniden bir bedel hesabının yapılarak ne tahsis sahibi ne de kamu adına bir kaybın oluşmaması sağlanmalıdır.

Bununla birlikte, tahsis amacı değişmemiş, daha önce bedel hesabı yapılmış temdit yerler için Uygulama Yönetmeliği'nin 3'ncü maddesi 1'nci fikrası (h) bendinde ifade edilen Bedel Artış Katsayısı (BAK) kullanılmalıdır. Bu bende göre "BAK her yıl bir önceki yıla ilişkin olarak 04.01.1961 tarihli ve 213 sayılı Vergi Usul Kanunu Uyarınca belirlenen yeniden değerleme oranını" ifade etmektedir. Yönetmelik'in 20. Maddesi (3) numaralı fikrasında ise "Arazi izin bedeli izin başlanglç tarihi esas allnarak bildirime gerek kalmaksizın her yıl defaten izin sahibi tarafindan ödenir. Müteakip yıllara ait arazi izin bedeli BAK oranında artırlmak suretiyle tespit edilerek bildirime gerek kalmaksızın izin başlangıç tarihinde defaten izin sahibi tarafindan ödenir" hükmü yer almaktadır. Nitekim OGM'nin 02.12.2015 tarih, 2602944 sayı ve "2016 yılı BAK oranı ve izin bedellerinin tahakkuk işlemleri” konulu yazısında "2016 yılı BAK katsayısinın \%5,58 olarak uygulanmasının, 2016 birim fiyatları yayınlanıncaya kadar bir önceki yil birim fiyatlarına göre hesaplanan proje maliyet bedellerinin 2016 yıl BAK oranı olarak tespit edilen \%5,58 oranında artırılması" emredilmiştir.

İncelenen örnek olayda, altyapı tesis alanları olarak izin verilen yerlerden bir önceki yıl 7,51 TL/m², açık işletme sahalarından ise $5,24 \mathrm{TL} / \mathrm{m}^{2}$ arazi izin bedeli alındığı saptanmaktadır. Yönetmelik'in süre uzatımı - temdit gören sahalarla ilgili yukarıda belirtilen BAK hükmü ve OGM'nin 2016 yılı için 5,58 katsayısının kullanılmasını emreden yazıs1 dikkate alındığında, açık işletme sahalarından 5,53 $\mathrm{TL} / \mathrm{m}^{2}(5,24 \mathrm{X} 5,58)$, altyap 1 tesis alanlarından ise $7,92 \mathrm{TL} / \mathrm{m}^{2}(7,51 \mathrm{X} 5,58)$ birim bedel üzerinden yeniden arazi izin bedeli hesaplaması gerektiği görülmektedir. Bu nedenle, Tablo 5'in İşlem başlıklı sütununun temdit yazan satırlarında, bedele konu alanlar BAK uygulanarak hesaplanmış birim bedellerle çarpılarak 2016 Arazi izin bedelleri bulunmuştur.

\subsubsection{Teminat bedelinin hesaplanması}

Uygulama Yönetmeliği’nin 22. maddesi teminatın "bir hektar için cari yıl ağaçlandırma bedelinden az olmamak kaydıyla, cari yıl ağaçlandırma bedelinin onda biri ile izin alanının çarpımı sonucu" bulunacağını hükme bağlamıştır. Buna göre; cari yıl ağaçlandırma birim bedeli olan 1,61406 TL'nin onda biri ile $(0,161406)$ izin verilen toplam alan
$(387.436,58)$ çarpıldığ 1 da $62.534,59$ TL teminat bedelinin elde edilmesi gereklidir.

\section{Araştırma Bulguları}

\subsection{6'ncı madde uygulama yönetmeliği'nin içerdiği boşluklar}

16'ncı Madde Uygulama Yönetmeliği'nin tanımladığ1 ve yukarıda bir örnekle gösterilen değer belirleme mantığını; ağaçlandırma, arazi izin ve teminat bedeli hesapları için ayrı ayrı ele almak daha açıklayıcıdır.

Ağaçlandırma bedeli hesabı incelendiğinde, hesaplama işleminin tamamen asgari ücret komisyon kararına endekslendiği, izin sahasının yapısı ile ağaçlandırma maliyetlerinin ilişkisinin dişlandığ1 görülmektedir. Sahaya özgü, eğim, toprak tipi, ağaç türü, toprak işleme ve 1slah ihtiyacı vb. maliyet kalemleri ile ağaçlandırma birim fiyatları dikkate alınarak bir ağaçlandırma maliyet hesaplanması en gerçekçidir. $\mathrm{Bu}$ nedenle, yıllardır projeli ağaçlandırma işleri yapan ve bugün de ağaçlandırma uygulama projelerinden sorumlu bir kurum olan OGM'nin bedel tespitini, sahaya özgü ağaçlandırma bedeli hesabı yapmak yerine, asgari ücret gibi, tamamen sektör dişı ve politik etkilerin altında alınan bir değişkene bağlaması eksikliktir.

Ağaçlandırma bedeli konusunda bir diğer düzenleme ihtiyacı bedel hesabına konu alan miktarının kararlaştırılması noktasındadır. Ağaçlandırma bedeli bir defa alınmakta fakat maden işletmesinin kullandığ 1 alan, yeni izin talepleri ve amaç değişimlerine bağlı olarak düzenlenen yeni olurlarla sürekli değişmektedir. Yönetmelik ağaçlandırma bedeli alınan ve alınacak alanların zaman içerisinde izlenme yaklaşımına ilişkin hükümler içermemektedir.

Arazi izin bedeli hesabıyla ilgili olarak Yönetmelik'in ilk boşluğu beş hektar istisnasının nasıl uygulanacağı noktasındadır. Yukarıdaki hesaplama örneğinden de görüldüğü gibi, izin türü katsayıları ile ekolojik denge katsayılarının hesaplanan arazi izin bedeli üzerinde etkisi bulunmaktadır. Bir an için orman idaresinin tahsis sahibinden yüksek (düşük) bedel almak maksadıyla hesaplama yapmak istediği varsayıldığında, beş ha indirimini Tablo 2 ve 3 'teki en düşük (en yüksek) katsayıya sahip yerlerden düşebileceği görülecektir. Benzer belirsizlik indirimin yeni başvuru alanlardan mı yapılacağı, yoksa süre uzatımı istenen, bir önceki yıl bedeline göre BAK kadar bedel artışı yapılacak sahalardan mı düşüleceği şeklinde de ifade edilebi- 
lir. Gerçekten de Yönetmelik'in bugünkü hükümlerine göre; Tablo 5'te örneği gösterilen ve farklı nitelikteki arazilerin toplam içerisindeki payı oranında beş ha indiriminin yapıldığı hesaplama örneğini, daha yüksek veya daha düşük bulacak şekilde hesaplamak mümkündür.

Arazi izin bedeli değer fonksiyonunun önemli bir değişkeni, izin türü katsayısıdır ve Uygulama Yönetmeliği'nin Ek 1'inde (Tablo 2) 0,2 ile 1,5 arasında değerlerle ifade edilmiştir. Buna ek olarak, 16'ncı Madde Uygulama Yönetmeliği'nin 3'ncü maddesi 1'nci fikrası (b) bendinde “Altyap tesisi: Madencilik faaliyetleri için zorunlu yol, su, röle istasyonu, haberleşme, enerji nakil hattı, trafo, bant konveyör, havai hat, asansör, havalandırma bacasl, galeri girişi, şantiye alani, yemekhane, atölye, maden stok alanı, pasa döküm alanı, verimli toprak depolama alanı, atık barajı, patlayıcı madde ve müştemilatı deposu ve kantar tesislerini" ifade eder" denilmektedir. Ancak, Tablo 1'de örnekleri görülen izin başvuru ve olurlarında geçen ifadelerle, yönetmelikteki ifadelerin uyumlu olduğunu söylemek güçtür. Yönetmelik hükümlerinin içerdiği tanımlarla, izin başvuru ve olurlarında kullanılan terminoloji, izin tür katsayısının kullanılması konusunda tereddüt oluşturmayacak netlikte olmalıdır.

Diğer yandan, izin türü katsayısı diye bir değişkene neden gerek duyulduğunun da açıklanması gereklidir. Eğer arazi kullanım şekli değiştiğinde, ormanlara verilen zarar veya ormancılık yapamamaktan doğan kayıplar değişiyorsa, böylesi bir değişkene ihtiyaç vardır. Ancak, bu konuda mantıklı bir açıklama, bilimsel çalışmalara dayalı kanıtlar getirilemiyorsa, izin türü değişkenin arazi izin bedelini etkilemesini açıklamak güçtür.

Benzer sorun ekolojik denge katsayısı için de geçerlidir. Meşcere yapısı; 1 kapalıdan 3 kapalıya doğru gidildikçe, toprağ 1 daha iyi örten, daha yoğun bir orman örtüsünün oluştuğu açıktır. Nitekim OGM de, ekolojik denge katsayılarını kapalılık arttıkça, 1'den 2'ye doğru artırmış (Tablo 3), ormandaki değer kaybının artacağını kabul etmiştir. $\mathrm{Bu}$ kabul, odun üretimi, toprak koruma gibi orman mal ve hizmetleri için geçerli varsayılsa bile, örneğin yaban hayatı, havzada toplanan su miktar ve kalitesi, biyolojik çeşitlilik temelli ormancılık değerlerinde kabul edilemez bir durumdur. Bu nedenle, Uygulama Yönetmeliği’nin kurguladığ ekolojik denge katsayılarının aslında ormanların temelde odun hammaddesi üretimi, biraz da su ve toprak koruma yeteneklerinin dikkate alınarak belirlendiği görülmektedir. Üstelik meşcere tipleri ve çağlarının farklılığ veya seçme oluşu da dikkate alınmamıştır. Bu gerekçelerle OGM'nin ekolojik denge katsayılarını, kapalılık arttıkça, 1'den 2'ye doğru artırması hem ekolojik hem iktisadi kayıplarını telafi edebilmesi açılarından doğru fakat yetersiz bir yaklaşımdır.

Yetersizliği iki noktada açıklamak mümkündür. Birincisi, odun üretimi veya toprak koruma bakımından tam kapalı bir ormanın ürettiği değer 2 katsayısı ile temsil edilebiliyorsa, ağaçsız alanların üretim yeteneği bunun yarısı kadar mıdır ki, Tablo 3'te orman ağaçları taşımayan yerlerde 1 katsayısının kullanılması uygun görülmektedir. Bu durumu, kapalılık \%10'dan \%11-40 aralığına çıktığında ormanın üretim değerinin neden 1,1'den 1,4'e çıktığ 1 örneğiyle de göstermek olanaklıdır. Ekolojik denge katsayılarının içerdiği ikinci yetersizlik, ormanın kullanım dışı değerlerinin kapalılık ile ilişkilendirilmiş katsayılarla açıklanıp açıklanamayacağı noktasındadır. Örneğin \%11-40 kapalı bir ormanın av yaban hayatı açısından, su üretim yeteneği bakımından veya biyolojik çeşitlilik değeri bakımından tam kapalı bir ormandan daha değerli olduğu söylenebilir. Ancak, Yönetmelik'in oluşturduğu katsayılara göre, her zaman tam kapalı bir orman tüm orman değer veya işlevleri bakımından diğer ormanlardan daha değerlidir kabulünün yapıldığ1 ortaya çıkmaktadır.

Bir an için ekolojik denge katsayılarının bilimsel yöntemlerle belirlendiği kabul edildiğinde dahi, Uygulama Yönetmeliği'nin Tablo 3'te gösterdiği katsayıları tahsis alanına başarıyla uygulayabilmek güçtür. İncelenen örnek olayda, izin taleplerinin toplam alan şeklinde yapıldığı görülmüştür. $\mathrm{Bu}$ nedenle, madencilik amacı farklı her izin noktası için, ormanın hangi noktasında işlem yapılacağı, meşcere haritalarıyla karşılaştırılabilir şekilde talep edilmedikçe, ekolojik denge katsayılarını başarıyla uygulamak güçtür.

Arazi izin bedeli hesabını etkileyen bir diğer değişken olan il katsayısı için Uygulama Yönetmeliği'nde 6 grup oluşturulmuş ve minimum 1,2 ile maksimum 3 arasında değişen katsayılar üretilmiştir. Bu katsayılara göre, en yüksek bedelin İstanbul ili sınırları içerisinden talep edilmesi gerekmektedir. Öncelikle bir ormanın, ormancılık dışı bir başka kullanıma tahsis edilmesinin, tahsis edilecek yerin bağlı olduğu il ile bağlantısının açıklanması gereklidir. Tahsis yapılan orman alanının herhangi bir emlak olması halinde, emlak piyasasındaki talebin illere göre değiştiği dikkate alınarak, böylesi 
bir katsayının gerekliliği makul görülebilir. Ancak, bu halde dahi, katsayılar emlak değerleri veya taleple ilişkilendirilerek oluşturulmalıdır. Uygulama Yönetmeliği’nde yer alan il katsayıları incelendiğinde, kentleşmenin yoğun, endüstrileşmenin yüksek olduğu illerde katsayının artırıldığ1 görülmektedir. Oysa bir ilin sahip olduğu orman alanı toplam il alanı içerisinde ne kadar düşük kalıyorsa veya ilde kişi başına düşen orman alanı ne kadar az ise bunu temel alınarak bir il katsayısı oluşturmak, ormanın o ildeki değerini temsil eden daha iyi bir değişken olabilir.

Örnek uygulama açıklanırken de belirtildiği gibi, Uygulama Yönetmeliği'nin kurgusu gereği, farklı kullanım amaçlarında farklı izin katsayıları kullanıldığ1 için, bir yerin tahsis amacı değiştiğinde yeniden değer belirlemek teknik bir zorunluluktur. Ancak bu zorunluluk yönetmelikte açıkça belirtilmemiş, dikkatle incelenerek anlaşılabilecek bir biçimde ortaya konmuştur. Benzer durum amaç değişmeden tahsis süresi devam eden yerlerin sonraki y1l tahsis bedellerinin hesabı konusunda da vardir. Yönetmelikte, hangi yerlerde yeni başvuru gibi bir değer belirleme yapılacağı, hangi yerler için BAK uygulanacağı açıkça ifade edilmelidir. Özellikle BAK uygulamasında hangi bedel üzerinden değer artışı yapılacağı net bir şekilde ortaya konmalıdır.

Yönetmelikte açık olmayan bir başka husus, bedel hesaplama zaman ve süreleri noktasındadır. İzin talepleri yılın her döneminde yapılmakta, tahsis olurları her zaman ve farklı süreler için verilmektedir. Yönetmelik yıllık bedel hesaplanacağını ifade etmekte fakat artık yılların veya tahsis iptallerinde iade edilmesi gereken alacağın hesaplanma yaklaşımını açıklamamakta ve ileride doğabilecek başkaca uyuşmazlıklara zemin hazırlamaktadır.

\subsection{6'ncı madde uygulama yönetmeliği hesaplama yaklaşımının değer belirleme yöntemleriyle karşılaştırılması}

Bir örnek çözümle tanıtılan ve boşlukları yukarıda belirtilen OGM'nin arazi izin bedeli ve ağaçlandırma bedeli hesabı yaklaşımının, yine yukarıda tanıtılan evrensel değer belirleme yöntemlerinin dayandığ1 pazar fiyatlarl, üretim fonksiyonları, açıklanmış tercihler, belirtilen tercihler, maliyete dayanan yöntemler veya fayda transferi yöntemlerinden hangisine, ne kadar uyum sağladığı ayrı ayrı incelenmiştir.

Ormanların madenciliğe tahsisiyle oluşan refah kaybının tazmini için; madencilik nedeniyle mahrum kalınan orman faydalarının değerinin tahmin edilmesi, zarar gören ormanı yeniden tesis etmek için gerekli maliyet bedelinin saptanması gereklidir. Uygulama Yönetmeliği gereği alınan arazi izin bedelinin, kavramsal olarak "tahsis sürecinde ormanların ürettiği mal ve hizmetlerden kayıplara" karşılık gelmesi gereklidir. Ancak, yukarıda çözümlenen örnekten de anlaşıldığı gibi, arazi izin bedelinin hesaplanmasında ne pazar fiyatlarından yararlanılmakta, ne ormancılığın herhangi bir üretim fonksiyonuna atıf yapılmakta ne de toplumsal tercihlerle, transfer edilen faydalarla ilgilenilmektedir. Arazi izin bedeli hesaplanırken, alan ve katsayıların, birim ağaçlandırma bedeliyle çarpıldığ 1 dikkate alınarak, bir an için maliyetin temel alındığı düşünülebilse de, ağaçlandırma bedelinin hesabının kökünde asgari ücretin bulunduğu hatırlandığında, maliyetin sadece iş gücü giderleri çerçevesinde dikkate alınabildiği görülmektedir.

$\mathrm{Ne}$ arazi izin bedelinin ne de ağaçlandırma bedelinin hesaplanma şeklinin, ormanın herhangi bir faydayı üretme fonksiyonuyla ilgisi kurulmamıştır. Diğer yandan bu faydalardan mahrum kalan toplumun tercihleri, dolayısıyla refah kaybı ile ilgisi bulunmamaktadır. Bu açıdan arazi izin bedelinin hesaplanması, orman kaynaklarının kullanım ve kullanım dışı değerlerinin tahmin edilmesi için yukarıda açıklanan evrensel yöntemlerin hiçbiriyle örtüşmemektedir. Mevcut orman kaynağından izin süresince ve restorasyon tamamlanıncaya kadar elde edilecek odun hammaddesi, odun diş1 ürünler, rekreasyon, su kalitesini iyileştirme, toprağı, biyolojik çeşitliliği koruma, yaban hayatını barındirma vb. mal ve hizmetin kaybını hesaplayacak herhangi bir yöntem tasarımı yönetmelikte mevcut değildir. Bu nedenle, Hesaplanan yaklaşık 2 milyon TL bedeli (Tablo 5) arazi tahsisiyle oluşan ormancılık üretim kayıplarının veya yeniden orman kurma maliyetinin karşılığ 1 olarak görmek olanaklı değildir.

Yönetmelikte arazi izin bedelinin tahsis süresince her yıl alınması öngörülmekte, sahanın tahsis sonunda rehabilite edilmiş olarak teslim alınacağ 1 ifade edilmektedir. Ancak rehabilitasyonun ormanın tahsis başındaki işlevlerini yerine getirecek şekilde yapılması koşulu bulunmamaktadır. Süreklilik ilkesi gereği, sadece tahsis değil, alanın özgün işlevlerini kazanana kadar restorasyon süresince mahrum kalınan faydaların tahsis süresi sonuna indirgenmesi veya tahsis süresine paylaştırılarak tahsil edilmesi gerekir.

Tazminatın ikinci boyutu olan orman ekosisteminin restorasyonunun maliyetine ilişkin olarak Yö- 
netmelikte ağaçlandırma bedeli ve rehabilitasyon projesinden söz edilmektedir. Ağaçlandırma bedeli, kavramsal olarak yukarıda açıklanan yöntemlerden yerine koyma/restorasyon harcamaları yöntemlerine benzese de ölçüt ve kapsam olarak asgari ücrete endekslenmesi, yönetmeliği bu yaklaşımdan uzaklaştırmaktadır.

Yönetmelik'in 18. madde 1. fikrasına göre rehabilitasyon projesi, madenciliğin topoğrafik yapı üzerindeki orman kurmayı engelleyebilecek olumsuz etkilerinin giderilmesini, canlılar için geçici koşulların oluşturulmasını ve sahada toprak depolama olanaklarını içermektedir. Rehabilitasyon projesi hazırlama ve uygulama maliyetlerinin izin sahibine ait olması, maliyet kalemleri belirsiz olsa da yerine koyma/restorasyon harcamaları yöntemi ile uyumludur. Ancak ağaçlandırma çalışmasının yanında, rehabilitasyon projesinin de ormanın özgün işlevlerine kavuşana kadar yeni ağaçlandırılmış bir alanda gerekli restorasyon tekniklerini ve bakım çalışmasını kapsamadığı görülmektedir.

Yönetmelik bir bütün olarak incelendiğinde, tanımlanan yöntemde toplumun ormancılık değerleriyle ilgili tercihlerini yansıtacak bir bileşen içermediği anlaşılmaktadır.

\section{Tartışma, Sonuç ve Öneriler}

OGM'nin ülkemizin önemli bir tartışma alanı olan 16'ncı madde uygulamalarını bir yönetmelikle düzenleme çabası olumlu bir girişimdir. Yönetmelik bu haliyle, ülkedeki farklı madencilik girişimlerinden hızlı ve dengeli dağıtılmış bir bedel tahsil olanağı tanımaktadır. Fakat yönetmelikle getirilen hesaplama yönteminin, madenciliğin ormancılıkta neden olduğu kayıpların başarıyla tespiti için yeterli olduğunu söylemek zordur. Yönetmelik'in ortaya koyduğu hesaplama yaklaşımı ne evrensel değer belirleme yaklaşımlarıyla ne de ülkemizin bu konudaki birikimiyle uyumlu değildir. OGM'nin Miraboğlu (1979) ve Şahin (1992) örneklerinde görüldüğü gibi, tahsis edilen ormanların işletme şekillerini, idare sürelerini, ürün çeşitleri ve piyasa değerlerini dikkate alarak, elde edilen değer veya kayıpların zaman değerlerini dikkate alarak, bir yöntem tanımlaması gereklidir.

Bununla birlikte, orman değerlerinin belirlenmesi konusunda ülkemizde yetişmiş insan kaynağının yetersiz olduğu, evrensel yöntemlerin gerektirdiği veri toplama yükü ile analizler için gerekli ileri tekniklerin uygulanmasında güçlükler yaşandığı bir gerçektir. Bunlara rağmen, Orman Kanunu'nun 16 'nc Maddesinin Uygulama Yönetmeliği'nin ye- niden gözden geçirilmesi zorunludur.

Bu gözden geçirme sırasında, öncelikle hangi ormanlarda, ne tip izinlerde, hangi değerlerin hesaplanacağ1 ve hangi kayıpların tazmin ettirileceğinin sınıflandırılması yararlı olacaktır. Yönetmelik bu haliyle, madenciliğe başlanmasıyla üretime ara verilen ormanın yıllık gelirlerindeki kaybı hesaplayamadığ 1 gibi, ormanın yarattığ 1 odun üretimi dışındaki değerlerden hangilerini kapsadığını ifade etmemektedir. Hatta odun üretim kayıpları, baltalık ve koru şeklindeki orman yapıları veya ağaç türleriyle dahi ilişkilendirilmemiş durumdadır. $\mathrm{Bu}$ nedenle, yönetmelikte yapılacak bir sınıflandırma, evrensel değer belirleme teknikleriyle, değeri belirlenecek orman işlevlerinin ilişkilendirilmesini kolaylaştıracağı gibi, her bir değer ve teknik için özel değer belirleme süreçleri tasarlanmasına olanak sağlayacaktır.

Yönetmelik, sanki tahsis işi tek bir yıl yapılmış gibi düzenlendiğinden, zaman boyutu görülmemektedir. Oysa ormancılık uzun yılları kapsayan bir çalışmadır ve madenler de pek çok yıl için işletilmektedir. Zaman boyutunun yokluğu, ormanlardan yapılan yararlanma biçiminin kararlaştırılmamasına, dolayısıyla hangi mal ve hizmetlerden vazgeçildiğinin belirlenmemesine, farklı zaman noktalarındaki fayda veya maliyetlerin bugüne getirilmesi için gerekli iskontolama işleminin uygulanamamasına neden olmaktadır. Bu nedenle, Yönetmelik'in tahsis süresi ve zamanının hesaplara nasıl yansıtılacağı noktasında iyileştirilmesi gereklidir.

Şahin'in (1992) de belirttiği gibi, eski maden sahalarında yapılacak ağaçlandırmaların birim maliyeti orijinal orman toprakları üzerinde yapılacak ağaçlandırmalardan, özel teknikler gerektirdiğinden, daha masraflıdır. $\mathrm{Bu}$ nedenle, ağaçlandırma bedellerinin hesaplanmasında asgari ücrete endekslenmiş bir bedel tespiti uygun değildir. Bunun yerine, bugün uygulanacakmış gibi bir ağaçlandırma projesi hazırlayarak, maliyet hesaplamak hem evrensel değer belirleme yaklaşımlarından yerine koyma/restorasyon harcamaları mantığına hem hakkaniyete en uygun çözümdür. $\mathrm{Bu}$ yaklaşımın idare açısından yapılabilir bulunmaması halinde, o yıl ülkede veya iznin verildiği bölge müdürlüğü sınırları içerisinde yapılan maden restorasyon ağaçlandırmalarının ortalama maliyetini, ağaçlandırma bedeli olarak almak, Yönetmelik'in bugünkü yaklaşımına göre daha gerçekçidir. Diğer yandan, zamanla büyüklüğü değişen tahsis alanlarının ağaçlandırma bedellerinin tahsili konusunda; bedelin tahsisin yapıldığ 1 yıl içerisinde 
alınacağı ve sonraki olurlarda ağaçlandırma bedeli ödenmiş alan miktarlarının nasıl izleneceği yönetmelikte açıkça belirtilmelidir.

Arazi izin bedelinin hesabında, beş ha indiriminin yapılma şekli yönetmelikte netleştirilmeli, örnek çözümde yapıldığı gibi, farklı amaç veya statüdeki arazilerin toplam içerisindeki payları oranında beş ha dağıtılmalıdır.

Yönetmelikte, arazi izin bedelinin hesabında kullanılan izin türü ile ormanlara yapılan etki veya ormancılık kayıplarının ilişkisi konusunda bilimsel tespitler gerekmektedir. Bu haliyle, sondaj usulü maden aranan orman alanlarının neden 0,2 ile, maden arama, işletme ve hammadde üretim izinlerinin ise neden 0,4 katsayısıyla çarpıldığının bilimsel dayanağ 1 bilinmemektedir. Benzer şekilde, Yönetmelikte yer alan ekolojik denge katsayılarının ormanın tüm işlevleri göz önünde alınarak ve bilimsel çalışmalara dayalı olarak oluşturulması gereklidir. İzin türü, ekolojik denge veya izin verilen illerin bir katsayı şeklinde bir hukuki düzenlemeye girebilmesi için öncelikle belirtilen değişkenlerle ormana verilen kayıpların ilişkisini bilimsel yöntemlerle kanıtlamak ve idari kararlarla değil, bilimsel çalışmalarla bu katsayıları türetmek gereklidir.

\section{Kaynaklar}

Bann C, Clemens, M., 2001. Turkey forest sector review-Global environmental overlays program final report. Iksir Tanıtım Ltd.Sti, Ankara.

Bekiroğlu, S., 2002. Arazi ve Orman Değerinin Saptanması Konusunda Araştırmaları, (Ayvalık Örneği), İÜ Orman Fakültesi Dergisi Seri A, 52(2):95-123.

Brey, R., Riera, P., Mogas, J., 2007. Estimation of forest values using choice modeling: An application to Spanish forests. Ecological Economics 64(2): 305-312.

Carson, R. T., Wilks, L., Imber, D., 1994. Valuing the Preservation of Australia's Kakadu Conservation Zone. Oxford Economic Papers 46 (1994), 727 749.

Daşdemir, İ., 2011. Ormancılık İşletme Ekonomisi, Bartın Ü. Y. No: 5, OF Y. No: 3, 407 s.

Demirbugan, A., 2015. Maden Sahalarını Doğaya Kazandirma Projelerinin Ekonomik Değerlendirmesi: Yaylıktepe Sahası Uygulaması, Dumlupınar Üniversitesi Sosyal Bilimler Dergisi, Say143 (Ocak).

Deniz, T., Ok, K., 2016. Erozyon kontrolü çalışma- larında değer analizi. Journal of the Faculty of Forestry Istanbul University 66(1): 139-158.

Firat, F., Miraboğlu, M., 1962. Orman Kiymetlerinin Takdirinde Kullanılan Formüller ve Tatbikatına Ait Misaller, İÜ Yayın No: 968, OF Yayın No:81, 119 s.

Dickie, M., 2003. Defensive behaviour and damage cost methods. In: P. A. Champ, K. J. Boyle and T. C. Brown (Eds.), A Primer On Nonmarket Valuaiton, 395-444,.Kluwer Academic Publishers.

Fırat, F., 1967. Ormancılık İşletme İktisadı, İÜ Yayın No: 1242, OF Yayın No: 110, 296 sayfa.

Gillespie, R., Bennett, J., 2012. Valuing the environmental, cultural and social impacts of open-cut coal mining in the Hunter Valley of New South Wales, Australia. Journal of Environmental Economics and Policy 1(3):276-288.

Gimpel, J., 1996. Ortaçağda Endüstri Devrimi, Çeviren: Nazım Özüaydın, TÜBİTAK P. B. Kitapları 38, ISBN 975-403-061-8. 253 sayfa. Ankara.

Gümüş, C., 2016. Historical development of forestry education in the context of forest resources management in Turkey. Turkish Journal of Forestry 17(1), 93-98.

Gümüş, C., 2014. Osmanlıdan Günümüze Ormancılık Politikalarının Ormancılık Örgütlenmesi Üzerine Etkileri ve Güncel Sorunlar, II. Ulusal Akdeniz Orman ve Çevre Sempozyumu, 22-24 Ekim 2014 - Isparta.

Kaya, G., 2002. Pazarı Olmayan Ürünler Çerçevesinde Orman Kaynaklarının Değerinin Belirlenmesi. Doktora Tezi, İstanbul Üniversitesi Fen Bilimleri Enstitüsü, İstanbul.

Kaya, G., Özyürek, E., 2015. Kent ormanı anlayışıyla ODTÜ Ormanı manzarası için ekonomik değerin tahmin edilmesi. Ormancılık Araştırma Dergisi 2015/1, A, 1:2, 15-28.

Kazgan, G., 1993. İktisadi Düşünce veya Politik İktisadın Evrimi, Remzi Kitabevi, 6. Basım, ISBN 975-14-0392-8, 431 sayfa, İstanbul.

Kosenius, A. K., Horne, P., 2016. Welfare effects of mining externalities - a combined travel cost and contingent behavior study, Journal of Environmental Economics and Policy 5(3):265-282.

Madureira, L., Nunes, L. C., Borges, J. G., Falcão, A. O., 2011. Assessing forest management strategies using a contingent valuation approach and ad- 
vanced visualisation techniques: a Portuguese case study. J Forest Economics 17(4): 399-414.

Mazzotta, M., Wainger, L., Sifleet, S., Petty, J. T., Rashleigh, B., 2015. Benefit transfer with limited data: An application to recreational fishing losses from surface mining. Ecological Economics 119 (2015) 384-398.

Miraboğlu, M., 1979. Ormanlık Sahalarda Açık Maden İşletmelerinde Tazminat Hesabı, OGM Y. sira No: 624, Seri No: 16, 74 Sayfa. Ankara.

OGM, 2014. Orman Kanunu'nun 16'nc1 Maddesinin Uygulama Yönetmeliği. Resmî Gazete. 28976, 18 Nisan 2014.

Oviedo, J. L., Caparros, A., Campos, P. C., 2006. Contingent ranking versus choice experiments in an application to cork oak reforestations in Spain, II. AERNA Conference, June 2016.

Shapansky, B., Adamowicz, W., Boxall, P., 2003. Measuring Forest Resource Values: An Assessment of Choice Experiments and Preference Construction Methods as Public Involvement Tools. Department of Rural Economy, University of Alberta, Project Report 02-03. Edmonton.

Şahin, N., 1992. Açık Saha Maden İşletmelerinin Ormanlar Üzerindeki Zararlarının Hesaplanması,
İÜ Fenbilimleri E. Y. Lisans Tezi.

Türker, M. F., 2013. Ormancılık İşletme Ekonomisi, Ormancılık ve Tabiatı Koruma Vakfı, Yayın No 5, 287 Sayfa.

Türker M. F., Pak M, Öztürk, A., 2005. Turkey. In: Merlo, M., Croitoru, L. (Eds.), Valuing Mediterranean Forests: Towards Total Economic Value. CABI Publishing, Wallingford, Oxon, pp. 195-211.

Williams, A. M., 2011. The Impact of Surface Coal Mining on Residential Property Values: A Hedonic Price Analysis. University of Tennessee, Honors Thesis Projects.

Wilson, S. J., 2014. The Peace Dividend: Assessing the Economic Value of Ecosystems in B.C.'S Peace River Watershed. David Suzuki Foundation's Ontario and Northern Canada Department.

Windle, J., Rolfe, J., 2014. Valuation framing and attribute scope variation in a choice experiment to assess the impacts of changing land use from agriculture to mining. The 58th National Australian Agricultural and Resource Economics Society Conference, 4-7 February 2014, Port Macquarie, NSW. 